\title{
Escherichia coli O157:H7 attachment and persistence within root biofilm of common treatment wetlands plants
}

\section{Rachel J. VanKempen-Fryling \& Anne K. Camper}

NOTICE: this is the author's version of a work that was accepted for publication in Ecological Engineering. Changes resulting from the publishing process, such as peer review, editing, corrections, structural formatting, and other quality control mechanisms may not be reflected in this document. Changes may have been made to this work since it was submitted for publication. A definitive version was subsequently published in Ecological Engineering, [Vol. 98, January 2017], DOI\#:10.1016/j.ecoleng.2016.10.018.

VanKempen-Fryling RJ, Camper AK "Escherichia coli O157:H7 attachment and persistence within root biofilm of common treatment wetlands plants," Ecological Engineering, 2017 Jan;98:64-69. 


\title{
Escherichia coli 0157:H7 attachment and persistence within root biofilm of common treatment wetlands plants
}

\author{
Rachel J. VanKempen-Fryling ${ }^{\text {a }}$, Anne K. Camper b,* \\ a Center for Biofilm Engineering, Montana State University, Bozeman, MT 59717, USA \\ b Department of Civil Engineering and Center for Biofilm Engineering, Montana State University, Bozeman, MT \\ 59717, USA
}

Keywords: Wetlands, Escherichia coli O157:H7 Biofilms, Plants, Colonization

\section{ABSTRACT}

Pathogen retention and subsequent release within the rhizosphere of wastewater treatment wetlands may be a concern for human health. To address this concern, the enteric pathogen Escherichia coli 0157:H7 with a DsRed plasmid insertion was used as a model pathogenic organism in an open-air chemostat reac-tor with constant flow of simulated wastewater. Colonization and persistence of the organism was tracked on roots of two obligate wetland plant species, Carex utriculata and Schoenoplectus acutus, originally grown in pilot scale wetland reactors. Teflon nylon string, clean and with existing indigenous biofilm, was used as an inert surface control. Epifluorescence microscopy and qPCR were used to verify E. coli O157:H7 abundance for up to 1 week. Initial attachment was seen on all surfaces, with colonization decreasing through 1 week. qPCR showed preferential association of the pathogen with roots over the nylon. There was a significant difference between plant type; S. acutus showed significantly higher numbers compared to C. utriculata. E. coli O157:H7 binding and persistence on root surfaces may be a means of survival in treatment wetlands.

\section{INTRODUCTION}

Wastewater treatment is important for the environment and human health. Many alternative methods to conventional treat-ment have been researched (Tonderski, 2009), including using treatment wetlands (TW). TW are the adoption and adaptation of a wetland's ability to remove common contaminants in water. In general, TW have a nonpermeable layer to prevent leaching and are planted with single or mixed species plants in a medium of gravel or soil (Akratos and Tsihrintzis 2007; Baskar et al., 2014). TW can vary in terms of wastewater loading and retention time (Kotti et al., 2010; Austin 2014).

For wastewater treatment, TWs provide both aerobic and anaer-obic microniches (Faulwetter et al., 2009). Plant roots release oxygen as well as other exudates into the subsurface, providing an environment for aerobic bacteria to survive at depths below the dissolved oxygen level (Carballeira et al., 2016). This allows aero-bic processes such as nitrification and phosphorus removal, leaving the anaerobic matrix to continue other anaerobic reactions such as denitrification (Hench et al., 2003; Taylor et al., 2011).

The root biofilm of TW may also reduce pathogenic bacteria present in the wastewater (Licence et al., 2001; Boutilier et al., 2009; Zhang et al., 2016). Existing biofilm competition and pre-dation in the rhizosphere limits attachment and settling (Boutilier et al., 2009; Jasper et al., 2013). However, there is extensive research revealing that pathogens may survive and be released in effluent water (Barcina and Arana 2009; Liu et al., 2009; Paruch, 2011). Even a low count release, such as $\mathbf{1 0 0}$ cells for Escherichia coli 0157:H7, is enough to cause human infection and disease (Bitton, 2005; USEPA, 2013).

E. coli $0157: \mathrm{H7}$ is a food- and waterborne pathogen transmit-ted via the fecal-oral route, usually through contaminated water or vegetables (Licence et al., 2001; Dinu and Bach 2011; Ongeng et al., 2011). Previous research has shown a decrease of $E$. coli O157:H7 through TWs, however these studies are solely based on plate counts (Liu et al., 2009; Ongeng et al., 2011; García et al., 2013). Direct microscopy or molecular techniques for enumeration would likely reveal much higher survival, as well as the ability for later release. This is due to a phenomenon known as the viable but non-culturable (VBNC) state in which bacteria are no longer culturable on a plate but can be resuscitated from the environment when returned to growth-promoting conditions (Barcina and Arana 2009; Dinu and Bach 2011; Paruch, 2011). 
C. utriculata
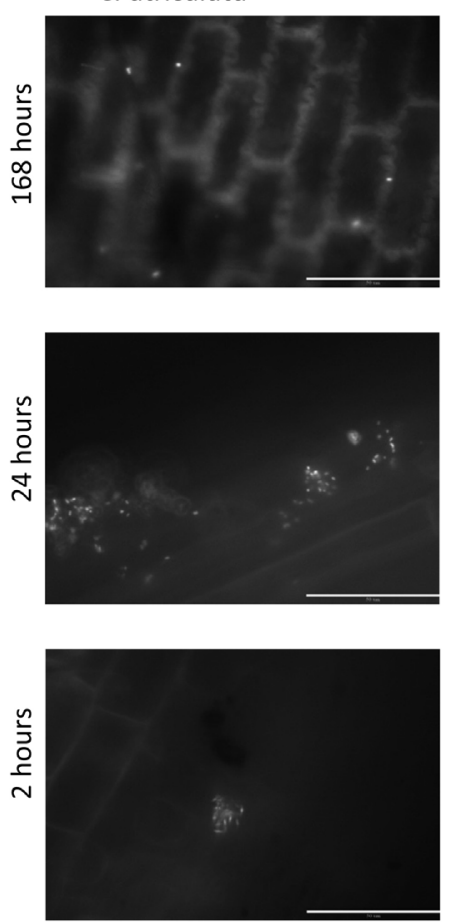

S. acutus
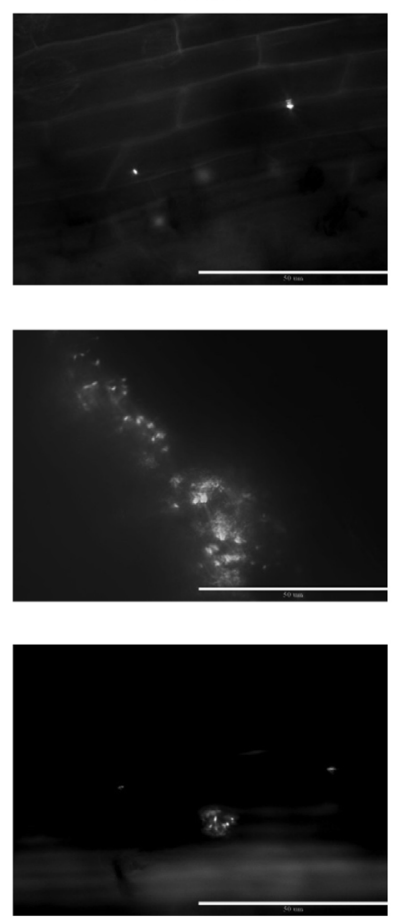

Teflon clean
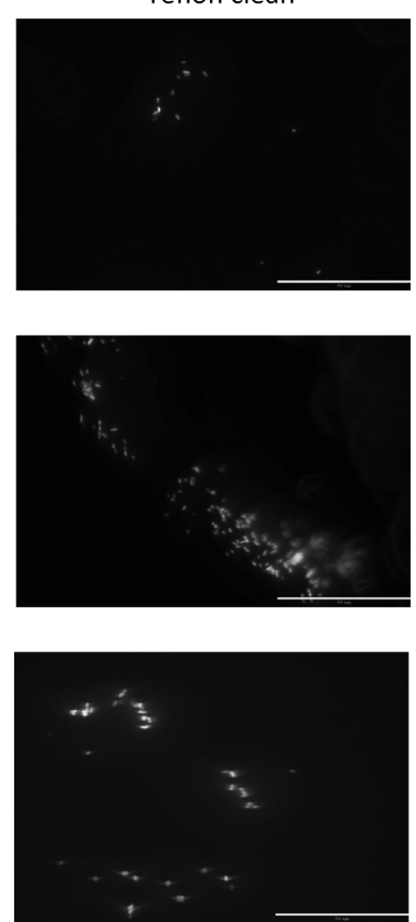

Teflon biofilm
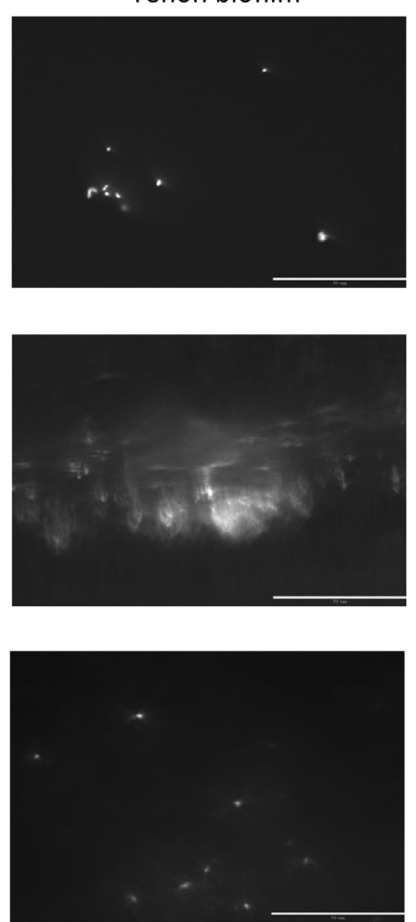

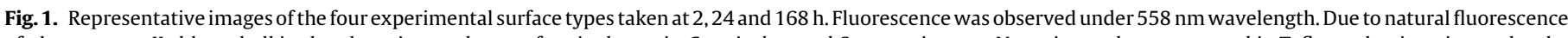

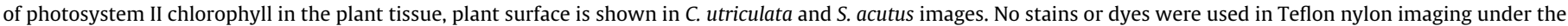
assumption stationary cells were attached to a surface. Scale bar represents $50 \mu \mathrm{m}$.

Another serious limitation is the focus on influent to effluent measurements, assuming that E. coli $0157: \mathrm{H} 7$ is not surviving within the TW. Long-term lab studies in river and reservoir water found E. coli 0157:H7 can persist up to 6 months (Liu et al., 2009). E. coli $0157: \mathrm{H7}$ may also be surviving within the biofilm matrix or incorporated into the plants, as seen in vegetable production (Fu et al., 2005; Dinu and Bach 2011) E. coli O157:H7 can invade plant tissues of leafy greens and stalks (Deering et al., 2012). Although this is not a health concern in TW as with edible plants, E. coli 0157:H7 within vascular openings of plants could provide means of survival and potential release.

The hypothesis was that indigenous biofilm and living plant tissue (with an established biofilm) impact the persistence of $E$. coli 0157:H7 in a simulated TW. Two plant species, C. utriculata and $S$. acutus, were used in hydroponic reactors to determine interactions with the roots. In previous research these two obligate wetland species were the top performers for removal efficiency of carbon, nitrogen and sulfate in pilot-scale wetland systems (Taylor et al., 2011). Inert Teflon nylon material was used as a control both with and without a pre-established biofilm. Pathogen persistence on these surfaces was assessed using qPCR and microscopy.

\section{Materials and methods}

\subsection{Growth of E. coli 0157:H7}

The E. coli 0157:H7 was isolated from an outbreak in 1993 (Pyle et al., 1995). A constitutively expressed DsRed plasmid with a carbenicillin resistance selective gene (Clonetech) was incorporated (Klayman et al., 2009) for detection by fluorescent microscopy. Tryptic Soy Broth (TSB) was made using non-casein enzymatic digest of protein (Klayman et al., 2009) for plasmid retention and expression. E. coli 0157:H7 was grown overnight to approximately $10^{8}$ cells $\mathrm{mL}^{-1}$ as determined by plate count. Survival and plasmid stability in simulated wastewater (SW; Supplemental Table 1) was verified by plate counts, qPCR, and epifluorescence microscopy (VanKempen-Fryling et al., 2015).

\subsection{Plant growth and strain collection}

Shoots with substantial root mass of $C$. utriculata and S. acutus grown in a controlled greenhouse environment were harvested and washed with nonsterile $\mathrm{H}_{2} \mathrm{O}$ to remove excess planting medium and loosely associated bacteria while keeping the attached biofilm. The rinsed plants $(49.3 \mathrm{~mL} \pm 26.4 \mathrm{~mL}$, determined by the mass displacement) were transferred to $300 \mathrm{~mL}$ hydroponic chemostat reactors under $24 \mathrm{~h} \mathrm{light}$ at $25^{\circ} \mathrm{C}$ and grown for 3-7 days in SW.

Comparisons were made between living roots to an inert surface of Teflon nylon strings (D'Addario; GHS strings) similar in dimensions to the roots $(0.79,0.81$ and $1.01 \mathrm{~mm}$ diameter $)$. Clean nylon strings were added to chemostats with SW immediately prior to E. coli 0157:H7 inoculation. Alternatively, strings were added to effluent of the established plant mesocosms for $24 \mathrm{~h}$ in batch, followed by the addition of SW (flow conditions) for 1 week to encourage biofilm growth prior to pathogen inoculation. Total weight of the nylon strings, cut into $17.5 \mathrm{~cm}$ lengths (half immersed), was $2.94 \mathrm{~g}$.

\subsection{Determination of surface area}

To estimate the E. coli 0157:H7 surface area attachment, standard curves were generated relating wet mass to root surface area. Representative roots were excised, imaged, and analyzed with the Rootscan ${ }^{\circledR}$ program to determine the surface area. The wet mass was plotted against surface area to generate standard curves (Supplemental Fig. 1).C. utriculata's two distinct root types (taproot and branched) formed unique standard curves; DNA extraction for $C$. utriculata samples were separated by root type. Teflon surface area was estimated by treating the strings as open ended cylinders. The 
A.

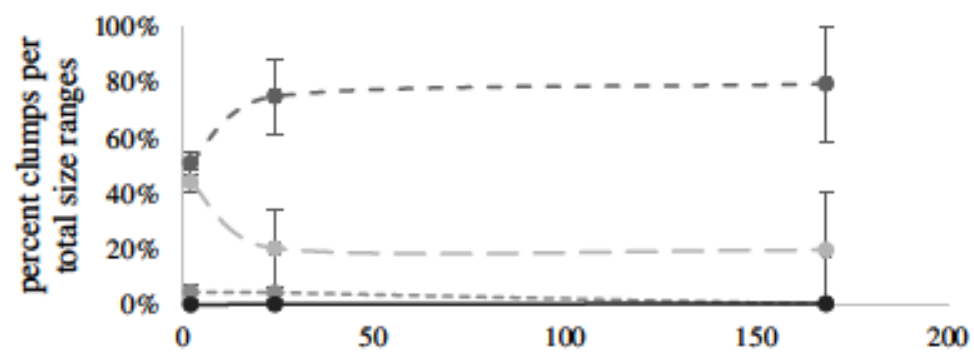

B.

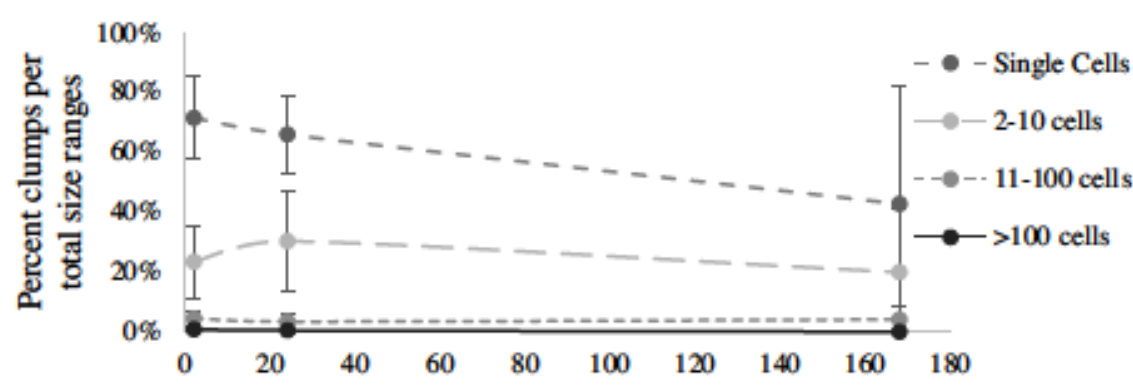

C.

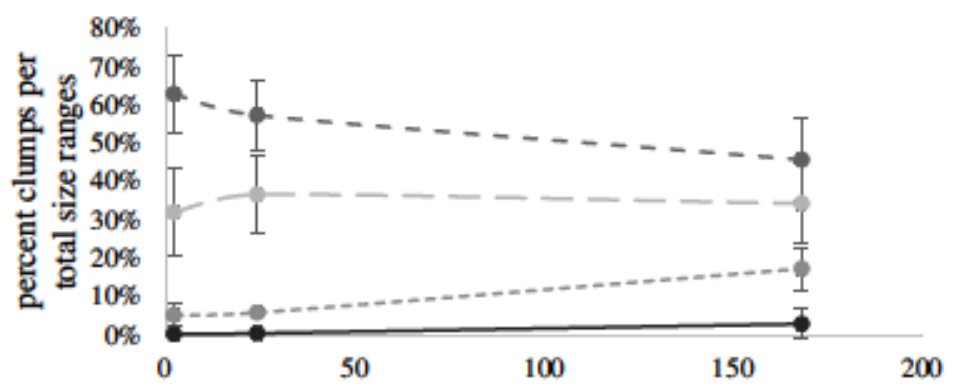

D.

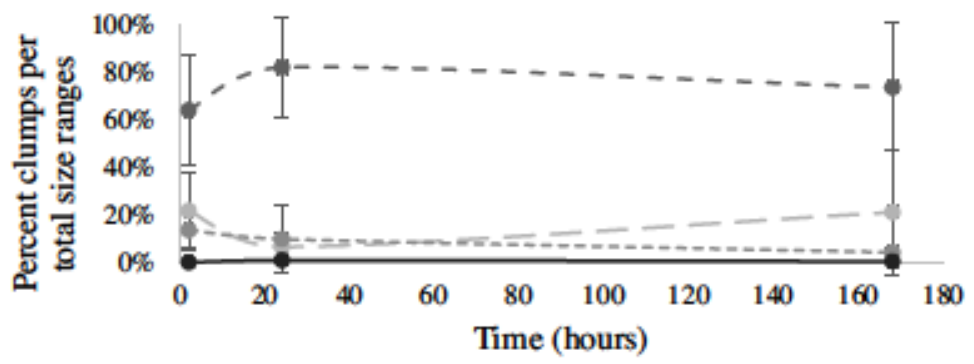

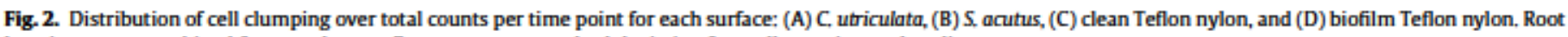
locations were combined for a total mean. Bars represent standard deviation from all experimental replicates.

total surface area of the 24 sample strings, 8 of each diameter was $53.32 \mathrm{~cm}^{2}$.

\subsection{Reactor series}

$20 \mathrm{~mL}$ of overnight $E$. coli $0157: \mathrm{H} 7$ culture was spun at $4816 \mathrm{xg}$ in triplicate, washed in nanopure water, and concentrated into $1 \mathrm{~mL}$. For each triplicate experimental condition (C. utriculata, $S$. acutus, clean nylon, and established biofilm nylon), $1 \mathrm{~mL}$ of inoculum was added and mixed via pipetting and rotating the plant or nylon. One additional non-inoculated reactor served as a control. Flow was at $3 \mathrm{~mL} \mathrm{~min}^{-1}$ (100 min hydraulic residence times (HRT)) for one week. A time zero sample was taken from each reactor immediately after inoculation. Effluent samples were collected at 45 -min intervals for $6 \mathrm{~h}$. One replicate reactor was destructively sampled at $135 \mathrm{~min}$, approximately 1 HRT (initial attachment). Another effluent sample was taken at $24 \mathrm{~h}$ and the second replicate reactor destructively sampled. The third replicate was destructively sampled at one week. The uninoculated control reactor effluent was sampled at 0 and $6 \mathrm{~h}$ and destructively sampled at one week. All water samples were frozen for further analysis.

Submerged roots from destructively sampled reactors were divided in half by length for differentiation of basal and root tip, rinsed with nanopure water to remove unattached cells, placed into $2 \mathrm{~mL}$ microcentrifuge tubes and frozen for DNA extraction. The nylon samples were taken in entirety, placed into $50 \mathrm{~mL}$ Falcon tubes, and frozen. A representative root or nylon sample was pulled through a $2 \mathrm{~mm}$ square glass capillary approximately $90-110 \mathrm{~mm}$ in length (Wale Apparatus, PA) using a wire hook (Aircraft Spruce), the interior of the capillary rinsed with nanopure water to slough off unattached cells, and attachment observed by epifluorescence microscopy.

\subsection{Epifluorescence microscopy}

The glass capillaries were viewed under $600 \times$ magnification (Nikon; Melville, NY) and $558 \mathrm{~nm}$ wavelength for DsRed plasmid excitation on a Nikon Eclipse E-800 microscope with a cooled CCD camera (Photometrics). The root tip, mid-root, and top root were 


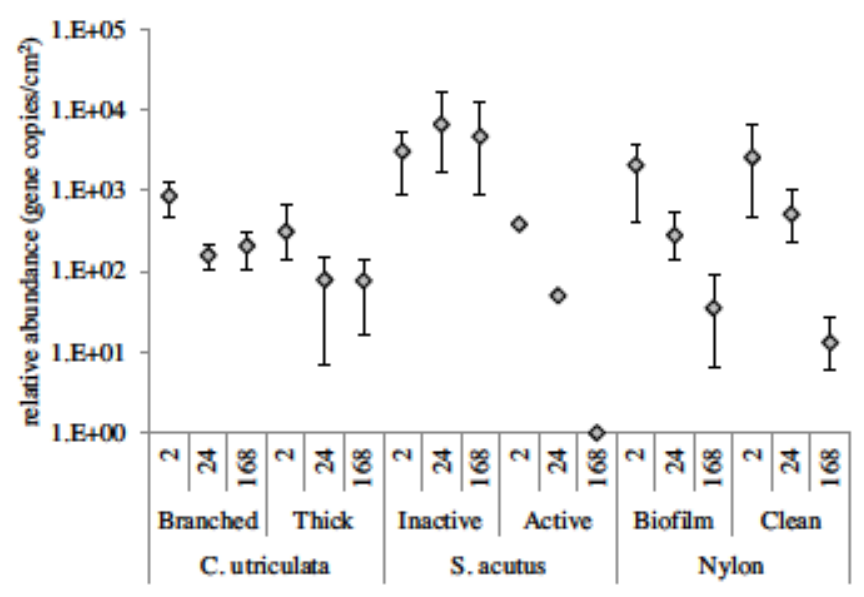

Fig. 3. Relative abundance of $E$, coli $0157: H 7$ per surface area normalized to background fluorescence. The data is differentiated over time and by root type or nylon condition for each respective surface.

Table 1

DNA extraction quantification.

\begin{tabular}{lll}
\hline Sample Type & $\begin{array}{l}\text { Concentration } \\
\text { (ng/uL) }\end{array}$ & $\mathrm{A}^{260 / 230}$ \\
\hline C. utriculata water & $80.08 \pm 40.56$ & $2.01 \pm 0.21$ \\
C. utriculata root & $96.38 \pm 30.02$ & $2.02 \pm 0.15$ \\
S. acutus water & $57.34 \pm 51.16$ & $1.49 \pm 0.61$ \\
S. acutus root & $72.09 \pm 37.17$ & $1.88 \pm 0.25$ \\
Nylon clean water & $59.81 \pm 29.91$ & $2.04 \pm 0.21$ \\
Nylon clean surface & $48.37 \pm 36.63$ & $1.94 \pm 0.70$ \\
Nylon biofilm water & $72.22 \pm 45.80$ & $1.95 \pm 0.48$ \\
Nylon biofilm surface & $40.03 \pm 24.86$ & $1.99 \pm 0.34$ \\
\hline
\end{tabular}

scanned and 20 images taken in each area for samples collected at 2, 24 and $168 \mathrm{~h}$. Natural photosystem II chlorophyll fluorescence allowed the plant surface to be viewed without stain. The images were semi quantitatively analyzed (MetaMorph ${ }^{\bullet}$ Image Analysis Software) to determine number of cells and colony clump size using the average pixel area for E. coli 0157:H7 single cell fluorescence (Wilson et al., 2004; Behnke et al., 2011). Thresholding was used to subtract background autofluorescence and remaining objects were counted.

\subsection{DNA extraction and $q P C R$ analysis}

Thawed water samples were spun down at $4816 \times \mathrm{g}$ for $20 \mathrm{~min}$ at $4{ }^{\circ} \mathrm{C}$. The pelleted sample was resuspended and transferred to a PowerBead tube from the PowerSoil ${ }^{\Phi}$ DNA Isolation Kit (MoBio Laboratories; Carlsbad, CA, USA). Mass of the roots was determined prior to transfer to a PowerBead tube. DNA extraction followed the kit protocol except a Fastprep ${ }^{\Phi}-24$ bead beater (M.P. Biomedicals; Santa Ana, CA, USA) was used at $5.5 \mathrm{~m} \mathrm{sec}^{-1}$ for $45 \mathrm{~s}$. Cell material on the nylon strings was removed by adding glass beads to the $5 \mathrm{~mL}$ mark of the $50 \mathrm{~mL}$ conical Falcon tube with $10 \mathrm{~mL}$ autoclaved nanopure $\mathrm{H}_{2} \mathrm{O}$, and vortexed for $60 \mathrm{~s}$. The liquid fraction was removed and centrifuged at $4816 \times \mathrm{g}$ for $5 \mathrm{~min}$. The supernatant was removed and the pellet resuspended and added to a PowerBead tube for extraction as previously described. DNA was isolated in $100 \mu \mathrm{L}$ of DEPC water (Ambion ${ }^{\oplus}$; Grand Island, NY, USA) and quantified using a Nanodrop ND-1000 spectrophotometer (Thermo Scientific; Wilmington, DE, USA). Average quantification and purity per sample type is listed in Table 1.

qPCR primers targeted the Shiga toxin 2 gene unique to the 0157:H7 serotype (Jothikumar and Griffiths, 2002). Control experiments using plate counts verified that the cells had one copy of the f Stx1 and Stx2 genes (Shaikh and Tarr, 2003). A $25 \mu \mathrm{L}$ reaction mixture was prepared using SYBR Green Master Mix (Kapa Biosystems; Wilmington, MA, USA), $0.5 \mathrm{mM}$ primer, and $3.1 \times 10^{-3} \mathrm{mM}$ DNA diluted from the extraction. Programs for $\mathrm{qPCR}$ can be found VanKempen-Fryling et al., 2015.

\subsection{Data analysis}

Multifactor analysis of variance (ANOVA) was performed to determine statistical significance between surface types and time. Comparisons were analyzed between plants and Teflon nylon strings, the root tip or basal root, established biofilm compared to clean nylon, and time. General linear models (GLM) were used to compare interactions using Minitab $17^{\circ}$. Statistical significance between specific factors for each variable were identified by pairwise Tukey's post hoc multiple comparison test using a 0.05 p-value cut-off. The experimental replicates were input as random variables nested within time.

\section{Results}

Initial washout of $E$. coli 0157:H7 during the first four HRT was similar for all systems (Supplemental Fig. 2). A twenty-four hour sample showed the continued release of $E$. coli 0157:H7 from the inoculated reactors, which would result from detachment of previously attached cells.

E. coli 0157:H7 could be imaged on the surfaces throughout the time course (Fig. 1). Initial attachment was mainly single cells and there was no observable difference in abundance by location or surface type. At $24 \mathrm{~h}$, microcolony formation was seen. The final time point at $168 \mathrm{~h}$ showed a lower, sustained E. coli 0157:H7 cell presence and more variable microcolony formation. These observations were substantiated with the MetaMorph ${ }^{\oplus}$ Image Analysis software (Fig. 2) and reported as a percentage of the total events for all size ranges from small and medium clusters to large, $>100$ cell formations. The number of clumps greater than single cells increased on all surfaces except the biofilm-colonized nylon, where increases were limited to clumps $>100$ cells. This is more dramatic in $S$. acutus (23 to 36 events) and clean nylon experiments (96 to 109 events). Single cells were more varied between replicates, as seen through the large error bars. The total clump counts decreased from 2 to $168 \mathrm{~h}$ (22.6 average events to 13.3 average events), however the largest formations increased (average increase of 1 event for $>100$ cell clump size).

qPCR determined relative target cell abundance on inoculated vs non-inoculated surfaces over time. For the root experiments, location (root tip or basal root) and condition (branched or thick for C. utriculata; red/live or black/dead coloration for S. acutus) of the root were analyzed. For nylon experiments, the biofilm presence/absence was compared. For all experimental surfaces (Fig. 3), the population decreased during the period between 2 and $168 \mathrm{~h}$, averaging a reduction from 704 gene copies $\mathrm{cm}^{-2}$ to 55 gene copies $\mathrm{cm}^{-2}(\mathrm{P}<0.001)$. Attachment on $S$. acutus was significantly higher (average 493 gene copies $\mathrm{cm}^{-2}$ ) than $C$. utriculata by 209 gene copies $\mathrm{cm}^{-2}(P=0.002)$, as well as both nylon replicates $(P=0.021)$ in all time points. Nylon replicates and $C$. utriculata were statistically equivalent with the lowest $E$. coli 0157:H7 attachment across all time points. For C utriculata, E. coli 0157:H7 preferred branched roots to uniform taproots with an average difference of 82.1 gene copies $\mathrm{cm}^{-2}$ to 281 gene copies $\mathrm{cm}^{-2}(\mathrm{P}<0.001)$ across all time points. In $S$. acutus, no meaningful effect of live roots was observed. Localization was taken into account between root tip and the basal roots, but there was no preference.

The two abiotic surfaces were also compared to identify any difference with respect to preexisting biofilm alone. There was no significant difference in E. coli 0157:H7 attachment. A slight inter- 
action between surface and time was seen from initial attachment to $24 \mathrm{~h}$ in clean nylon over biofilm-colonized nylon (Supplemental Fig. 3).

\section{Discussion}

Epifluorescence microscopy and qPCR showed that E. coli 0157:H7 attached and persisted on all surfaces under flow conditions for the duration of the experiment. Attachment was significantly lower on abiotic nylon controls compared to S. acutus roots. This supports the hypothesis that there is a benefit for survival or potential growth for bacterial pathogens within an established root biofilm (Tyler and Triplett 2008). Many plants have been shown to foster biofilm growth along the root structures for reasons ranging from protection against plant pathogens to nitrogen fixation (Gruyer et al., 2013). Wetland plants provide labile organic carbon exudates during active periods and by slow release during decay (García et al., 2010; Iannelli et al., 2011), and also contribute ions and oxygen (Hawkes et al., 2007). Given previous extensive research on interactions between plants and bacteria (Danhorn and Fuqua, 2007) it is possible that E. coli O157:H7 attachment and persistence may benefit from these interactions (Deering et al., 2012). Less attachment to C. utriculata roots suggests that this plant may have a lower potential for pathogen retention in TW.

Interestingly, there was no statistical difference in pathogen attachment and persistence between the clean nylon surface and nylon with an established biofilm. It was hypothesized that competition with the natural consortia of bacteria in an environment would protect against invading E. coli $0157: \mathrm{H} 7$ cells since this is common with other organisms (Hibbing et al., 2010) and pathogens in aquatic biofilms (Nocker et al., 2013). The mechanisms in this system remain unknown and will warrant further research.

The fate of the undetected E. coli O157:H7 cells and whether they were sloughed into the effluent feed and still viable or inactivated by predation or competition was not determined. Other studies have indicated these factors play a large role in lowering human pathogen retention in the environment (Boutilier et al., 2009; Jasper et al., 2013; Li et al., 2014), however for strains with a low infection rate such as E. coli O157:H7, these may not be enough to completely eradicate subsequent release and the potential infection. If $E$. coli 0157:H7 is able to attach to roots, it may have prolonged ability to survive in a TW. Further research is needed for optimizing pathogen removal in TW.

\section{Acknowledgements}

Betsey Pitts at the Center for Biofilm Engineering provided assistance with microscopy and the Land Resources and Environmental Sciences and Plant Sciences departments provided assistance with the plant work. This research was supported by the Molecular Biosciences Program Fellowship, the Montana Institute on Ecosystems, and the Center for Biofilm Engineering.

\section{Appendix A. Supplementary data}

Supplementary data associated with this article can be found, in the online version, at http://dx.doi.org/10.1016/j.ecoleng.2016.10. 018.

\section{References}

Akratos, C.S., Tsihrintzis, V.A., 2007. Effect of temperature, HRT, vegetation and porous media on removal efficiency of pilot-scale horizontal subsurface flow constructed wetlands. Ecol. Eng. 29, 173-191.

Austin, G., 2014. Green infrastructure for landscape planning. In: Routledge (Ed.), Integrating Human and Natural Systems. Routledge New York, New York.
Barcina, I., Arana, I.S., 2009. The viable but nonculturable phenotype: a crossroads in the life-cycle of non-differentiating bacteria? Rev. Environ. Sci. Biotechnol. 8, 245-255.

Baskar, G., Deeptha, V.T., Annadurai, R., 2014. Comparison of treatment performance between constructed wetlands with different substrates. Int. J. Res. Eng. Adv. Technol. 2 (3), 1-5.

Behnke, S., Parker, A.E., Woodall, D., Camper, A.K., 2011. Comparing the chlorine disinfection of detached biofilm clusters with those of sessile biofilms and planktonic cells in single- and dual-species cultures. Appl. Environ. Microbiol. 77 (20), 7176-7184.

Bitton, G., 2005. Wastewater Microbiology. John Wiley \& Songs, Inc., Hokboken.

Boutilier, L., Jamieson, R., Gordon, R., Lake, C., Hart, W., 2009. Adsorption, sedimentation, and inactivation of $E$. coli within wastewater treatment wetlands. Water Res. 43, 4370-4380.

Carballeira, T., Ruiz, I., Soto, M., 2016. Effect of plants and surface loading rate on the treatment efficiency of shallow subsurface constructed wetlands. Ecol. Eng. 90, 203-214.

Danhorn, T., Fuqua, C., 2007. Biofilm formation by plant-associated bacteria. Annu Rev. Microbiol. 61, 401-422.

Deering, A.J., Mauer, L.J., Pruitt, R.E., 2012. Internalization of E. coli 0157:H7 and Salmonella spp. in plants: a review. Food Res. Int. 45, 567-575.

Dinu, L.-D., Bach, S., 2011. Induction of viable but nonculturable Escherichia coli 0157:H7 in the phyllosphere of lettuce: a food safety risk factor. Appl. Environ. Microbiol. 77, 8295-8302.

Faulwetter, J.L., Gagnon, V., Sundberg, C., Chazarenc, F., Burr, M.D., Brisson, J., Camper, A.K., Stein, O.R., 2009. Microbial processes influencing performance of treatment wetlands: a review. Ecol. Eng. 35 (6), 987-1004.

Fu, Z., Rogelj, S., Kieft, T.L., 2005. Rapid detection of Escherichia coli 0157:H7 by immunomagnetic separation and real-time PCR. Int. J. Food Microbiol. 99, 47-57.

García, J.D., Rousseau, P.L., Morato, J., Lesage, E.L.S., Matamoros, V., Bayona, J.M., 2010. Contaminant removal processes in subsurface-flow constructed wetlands: a review. Crit. Rev. Environ. Sci. Technol. 40 (7), 561-661.

García, J.A., Paredes, D., Cubillos, J.A., 2013. Effect of plants and the combination of wetland treatment type systems on pathogen removal in tropical climate conditions. Ecol. Eng. 58, 57-62.

Gruyer, N., Dorais, M., Zagury, G.J., Alsanius, B.W., 2013. Removal of plant pathogens from recycled greenhouse wastewater using constructed wetlands. Agric. Water Manage. 117, 153-158.

Hawkes, C.V., DeAngelis, K.M., Firestone, M.K., 2007. Chapter 1 - root interactions with soil microbial communities and processes. In: Whitbeck, Z.G.C.L. (Ed.) The Rhizosphere. Academic Press, Burlington, pp. 1-29.

Hench, K.R., Bissonnette, G.K., Sexstone, A.J., Coleman, J.G., Garbutt, K., Skousen, J.G., 2003. Fate of physical, chemical, and microbial contaminants in domestic wastewater following treatment by small constructed wetlands. Water Res. 37 (4), 921-927.

Hibbing, M.E., Fuqua, C., Parsek, M.R., Peterson, S.B., 2010. Nat. Rev. Microbiol. 8 $15-25$.

Iannelli, R., Bianchi, V., Salvato, M., Borin, M., 2011. Modelling assessment of carbon supply by different macrophytes for nitrogen removal in pilot vegetated mesocosms? Int. J. Environ. Anal. Chem. 91 (7-8), 708-726.

Jasper, J.T., Nguyen, M.T., Jones, Z.L., Ismail, N.S., Sedlak, D.L., Sharp, J.O., Luthy, R.G., Horne, A.J., Nelson, K.L., 2013. Unit process wetlands for removal of trace organic contaminants and pathogens from municipal wastewater effluents. Environ. Eng. Sci. 30 (8), 421-436.

Klayman, B.J., Volden, P.A., Stewart, P.S., Camper, A.K., 2009. Escherichia coli 0157:H7 requires colonizing partner to adhere and persist in a capillary flow cell. Environ. Sci. Technol. 43, 2105-2111.

Kotti, I.P., Gikas, G.D., Tsihrintzis, V.A., 2010. Effect of operational and design parameters on removal efficiency of pilot-scale FWS constructed wetlands and comparison with HSF systems. Ecol. Eng. 36, 862-875.

Li, F., Shi, M., Zheng, X., Zhang, N., Zheng, H., Gao, C., 2014. A novel method of rural sewage disinfection via root extracts of hydrophytes. Ecol. Eng. 64, 344-349.

Licence, K., Oates, K.R., Synge, B.A., Reid, T.M.S.1, 2001. An outbreak of E.coli 0157 infection with evidence of spread from animals to man through contamination of a private water supply. Epidemiol. Infect. 126, 135-138.

Liu, Y., Wang C., Tyrrell, G., Hrudey, S.E., Li, X.-F., 2009. Induction of Escherichia coll 0157:H7 into the viable but non-culturable state by chloraminated water and river water, and subsequent resuscitation. Environ. Microbiol. Rep. 1, 155-161.

Nocker, A., Burr, M., Camper, A.K., 2013. Chapter 1. Pathogens in Water and Biofilms. In: Microbiology of Waterborne Disease, 2nd Edition. S. Percival, M.V. Yates, D., Williams, N. Gray and R. Chalmers, eds.

Ongeng, D., Muyanja, C., Ryckeboer, J., Geeraerd, A.H., Springael, D., 2011. Development and validation of a culture-based method suitable for monitoring environmental survival of Escherichia coli 0157:H7 and Salmonella enterica serovar Typhimurium in developing countries. Ann. Microbiol 61 (4), 809-817.

Paruch, A.M., 2011. Long-term survival of Escherichia coli in lightweight aggregate filter media of constructed wastewater treatment wetlands. Water Sci. Technol. 63 (3), 558-564.

Pyle, B.H., Broadaway, S.C., McFeters, G.A., 1995. A rapid, direct method for enumerating respiring enterohemorrhagic Escherichia coli 0157:H7 in Water. Appl. Environ. Microbiol. 61, 2614-2619.

Shaikh, N., Tarr, P.I., 2003. Escherichia coli 0157:H7 shiga toxin-encoding bacteriophages: integrations, excisions, truncations, and evolutionary implications. J. Bacteriol. 185 (12), 3596-3605. 
Taylor, C.R., Hook, P.B., Stein, O.R., Zabinski, C.A., 2011. Seasonal effects of 19 plant species on COD removal in subsurface treatment wetland microcosms. Ecol. Eng. 37 (5), 703-710

Tonderski, K.S., 2009. Molecular and microbial advances in wetland science. Ecol. Eng. 35 (6), 959-960.

USEPA, 2013. Basic Information about E. coli 0157:H7 in Drinking Water, United States Environmental Protection Agency, http://water.epa.gov/drink/ contaminants/basicinformation/ecoli.cfm.
VanKempen-Fryling, R.J., Stein, O.R., Camper, A.K., 2015. Presence and persistence of wastewater pathogen Escherichia coli 0157:H7 in hydroponic reactors of treatment wetland species. Water Sci. Technol. 72 (1), 135-140.

Wilson, S., Hamilton, M.A., Hamilton, G.C., Schumann, M.R., Stoodley, P., 2004 Statistical quantification of detachment rates and size distributions of cell clumps from wild-type (PAO1) and cell signaling mutant (JP1) Pseudomonas aeruginosa biofilms. Appl. Environ. Microbiol. 70 (10), 5847-5852.

Zhang, D., Luo, J., Lee, Z.M.P., Maspolim, Y., Gersberg, R.M., Liu, Y., Tan, S.K., Ng, W.J. 2016. Characterization of bacterial communities in wetland mesocosms receiving pharmaceutical-enriched wastewater. Ecol. Eng. 90, 215-224. 